OPEN ACCESS

Approved by:

Frontiers in Immunology Editorial

Office,

Frontiers Media SA, Switzerland

*Correspondence:

Frontiers Production Office production.office@frontiersin.org

Specialty section:

This article was submitted to Cancer Immunity and Immunotherapy, a section of the journal

Frontiers in Immunology

Received: 13 August 2020

Accepted: 14 August 2020

Published: 31 August 2020

Citation:

Frontiers Production Office (2020) Erratum: Editorial: NKT Cells in Cancer Immunotherapy.

Front. Immunol. 11:594504. doi: 10.3389/fimmu.2020.594504

\title{
Erratum: Editorial: NKT Cells in Cancer Immunotherapy
}

\author{
Frontiers Production Office * \\ Frontiers Media SA, Lausanne, Switzerland
}

Keywords: iNKT, CD1d, dendritic cells, $\alpha$-GalCer, cancer, immunotherapy

\section{An Erratum on}

Editorial: NKT Cells in Cancer Immunotherapy

by Webb, T. J., Yuan, W., Meyer, E., and Dellabona, P. (2020). Front. Immunol. 11:1314. doi: $10.3389 /$ fimmu.2020.01314

Due to a production error, reference 5 was incorrectly written as "Shissler SC, Webb TJ. The ins and outs of type I iNKT cell development. Mol Immunol. (2019) 105:116-30. doi: 10.1016/j.molimm.2018.09.023." It should be "Shissler SC, Lee MS, Webb TJ. Mixed signals: co-stimulation in invariant natural killer T cell-mediated cancer immunotherapy. Front Immunol. (2017) 8:1447. doi: 10.3389/fimmu.2017.01447".

The publisher apologizes for this mistake. The original article has been updated.

Copyright $\odot 2020$ Frontiers Production Office. This is an open-access article distributed under the terms of the Creative Commons Attribution License (CC BY). The use, distribution or reproduction in other forums is permitted, provided the original author(s) and the copyright owner(s) are credited and that the original publication in this journal is cited, in accordance with accepted academic practice. No use, distribution or reproduction is permitted which does not comply with these terms. 